\title{
UJI EFEKTIVITAS WAKTU PEMANGKASAN TOPPING TERHADAP PERTUMBUHAN DAN HASIL KACANG PANJANG (Vigna sesquipedalis (L) fruhw)
}

\author{
(Effectiveness Of Topping Time On The Growth And Year Of Long Beans \\ (Vigna sesquipedalis (L) fruhw)
}

\author{
Dhiar Hamdani ${ }^{1}$, Sulistyo Sidik Purnomo ${ }^{1}$, Rommy Andhika Laksono ${ }^{1}$ dan Prasodjo \\ Soedomo $^{2}$ \\ ${ }^{1)}$ Program Studi Agroteknologi, Fakultas Pertanian, Universitas Singaperbangsa Karawang \\ Jl. HS Ronggowaluyo, Teluk Jambe Timur, Kab. Karawang 41361 \\ ${ }^{2)}$ Peneliti Balai Penelitian Tanaman Sayuran Lembang \\ Jl.Tangkubanperahu No 517 Lembang - Bandung Barat 40391 \\ Penulis Koresponden: dhiarhamdani97@gmail.com
}

Article Submitted: $12-02-2021$

Article Accepted: 20-05-2021

\begin{abstract}
Long beans are a food favored by Indonesian people because they have sufficient nutritional content for health. topping is a way to increase production. This study aims to determine the growth response and interaction of two varieties of Long Beans with different topping times. The research was conducted in Karawang Regency in July - August 2020. The method used was a randomized block design method with a split-plot design consisting of 2 factors. the first factor was the variety (v) with 2 levels, v1 (KP-1) and v2 (Katrina) with 4 replications. The second factor is the pruning time (p) with 3 levels, p0 (without trimming), p1 (pruning 20 days afterward), and p2 pruning 40 days afterward. If the treatment shows a significantly different effect, then proceed with the LSD 5\% test. The results showed that the KP-1 variety with pruning treatment of 20 days after planting gave the highest yield with 348.20 grams per plant. Meanwhile, the highest yield of Katrina variety was in the treatment without pruning with a weight of 370.70 grams per plant.
\end{abstract}

Keywords: long beans, varieties, pruning time, topping.

\section{PENDAHULUAN}

Kacang panjang merupakan tanaman sayuran yang juga menjadi sumber protein nabati dan mineral. Fungsinya sebagai pengatur metabolisme tubuh, meningkatkan kecerdasan dan ketahanan tubuh serta memperlancar proses pencernaan karena kandungan seratnya yang tinggi (Rasyid, 2012). Produksi kacang panjang di Indonesia sepanjang lima tahun terakhir mengalami penurunan yang signifikan.

Pada tahun 2014 produksi kacang Indonesia sebesar 450.727 ton kemudian pada tahun 2015 produksinya menurun menjadi 395.524 ton, dan pada tahun 2018 hasil tanaman kacang panjang di Indonesia sebesar 370.202 ton (Badan Pusat Statistik, 2018).

Salah satu penyebab rendahnya produktivitas kacang panjang di Indonesia adalah kebiasaan petani yang secara dominan masih menggunakan kultivar atau varietas lokal hasil perbanyakan sendiri. Selain karena alasan ekonomis, hal ini juga disebabkan oleh masih terbatasnya ragam dan ketersediaan varietas unggul Kacang panjang di pasar. Oleh karena itu upaya 
peningkatan produktivitas harus didukung oleh perbaikan sistem perbenihan melalui percepatan introduksi dan desiminasi varietas-varietas unggul baru Kacang panjang (Soedomo, 2012).

Selain menggunakan varietas unggul, pemangkasan juga mempengaruhi produksi kacang panjang. Tindakan pemangkasan Kacang panjang dapat dilakukan dengan memangkas bagian pucuk tanaman (topping). Hal ini perlu dilakukan untuk mengatasi masalah persaingan. Tanaman dengan perllakuan pemangkasan asimilasinya ditranslokasikan ke generatif sehingga hasil buahnya akan lebih besar dan baik. Hal inilah yang nantinya diharapkan dari pemangkasan topping kacang panjang agar hasil asimilasinya ditranslokasikan seluruhnya pada pembentukan bunga dan pertumbuhan polong segar kacang panjang.

Jumlah auksin yang berlebih pada tanaman mempengaruhi proses dormansi pucuk yang menghambat tunas dibawahnya untuk tumbuh. Dengan dilakukannya pemangkasan topping akan mempengaruhi produksi dan aliran auksin ke tunas-tunas lateral. Tercukupinya aliran asimilat diharapkan mampu meningkatkan jumlah dan berat polong segar (Simanjuntak et al, 2019).

Waktu pemangkasan berhubungan erat dengan laju metabolisme dan proses fotosintesis terutama dalam fase pertumbuhan tanaman dalam hal zink and soucre. sehingga waktu pemangkasan menjadi faktor yang mempengaruhi hasil dan pertumbuhan tanaman (Parawansa dan Rante, 2014). Dikuatkan oleh Badruddin et al. (2011) yang menyatakan bahwa waktu pemangkasan berhubungan erat dengan pertumbuhan dan hasil tanaman karena mempengaruhi proses fotosintesis dan juga laju metabolisme.

Badrudin et al., (2011) dalam penelitiannya menyatakan bahwa waktu pemangkasan pucuk mentimun (Cucumis sativus L) berbeda sangat nyata terhadap jumlah buah per tanaman sampel dan bobot buah per tanaman. Waktu pemangkasan pucuk pada fase vegetatif umur $14 \mathrm{hst}$ memberikan hasil terbaik. Sedangkan pada komoditi Baby Buncis (Phaseolus vulgaris L) waktu pemangkasan terbaik didapat pada saat tanaman berumur 35 hst, sesuai dengan penelitian Safitri dan Aini (2018) yang menyatakan bahwa pemangkasan pucuk 35 hst pada tanaman Baby Buncis (phaseolus vulgaris L) memberikan pengaruh awal panen tercepat dibandingkan dengan perlakuan tanpa pemangkasan.

Dalam penelitian yang dilakukan Sutrisno dan Wijanarko (2016) menyatakan bahwa Terdapat interaksi antara pemangkasan dan varietas terhadap jumlah buku subur. Sedangkan berdasarkan Kurniawati dan Guritno (2016), pemangkasan dan varietas memiliki interaksi pada pembetukan bunga jantan pada tanaman mentimun, dimana setiap varietas memiliki respon yang berbeda. Hal ini menunjukan bahwa setiap tanaman dan varietas memiliki respon yang berbeda terhadap waktu pemangkasan pucuk, sehingga perlu dilakukan penelitian agar dihasilkan panduan yang baik pada budidaya tanaman Kacang panjang.

\section{METODE PENELITIAN}

Penelitian dilaksanakan di Desa Sirnabaya, Kecamatan Teluk Jambe Timur, Kabupaten Karawang, pada bulan Juli 2020 sampai dengan bulan september 2020. Bahan yang digunakan selama penelitian adalah benih Kacang Panjang varietas KP-1 dan Katrina, pupuk kandang, pupuk anorganik, dan air. Sedangkan alat yang akan digunakan selama penelitian adalah cangkul, embrat, timbangan analitik, gunting, pensil, kertas, penggaris, kamera, cutter, label dan selotip, termohygrometer.

Penelitian ini menggunakan metode eksperimental dengan Rancangan Acak Kelompok pola split plot yang terdiri dari 2 faktor. Faktor pertama adalah v (varietas) dengan 2 taraf yaitu $\mathrm{v} 1=$ varietas KP-1 dan 
v2 = varietas Katrina. Sedangkan faktor kedua adalah $\mathrm{p}$ (waktu pemangkasan) dengan 3 taraf yaitu $\mathrm{p} 0=$ tanpa pemangkasan, $\mathrm{p} 1=$ pemangkasan $20 \mathrm{hst}$ dan $\mathrm{p} 2=$ pemangkasan 40 (hst) dengan 4 kali ulangan. Apabila perlakuan menunjukan pengaruh yang berbeda nyata maka dilanjutkan dengan Uji BNT 5\%.

\section{HASIL DAN PEMBAHASAN}

\section{Luas Daun}

Hasil analisis data menunjukan tidak ada pengaruh yang nyata antara perlakuan jenis varietas dan waktu pemangkasan topping terhadap luas daun tanaman Kacang Panjang. Sedangkan secara mandiri hanya perlakuan waktu pemangkasan saja yang menunjukan adanya pengaruh.

Tabel 1. Rerata Luas Daun $\left(\mathrm{cm}^{2}\right)$.

\begin{tabular}{lc}
\hline Perlakuan & Luas Daun $\left(\mathrm{cm}^{2}\right)$ \\
\hline Varietas (V) & $0.53 \mathrm{a}$ \\
v1 (KP-1) & $0.41 \mathrm{a}$ \\
v2 (Katrina) & \\
\hline Waktu Pemangkasan (P) & $0.47 \mathrm{a}$ \\
p0 (Tanpa Pemangkasan) & $0.60 \mathrm{a}$ \\
p1 (pemangkasan 20 hst) & $0.33 \mathrm{~b}$ \\
p2 (Pemangkasan 40 hst) & $32 \%$ \\
\hline KK (\%) &
\end{tabular}

Keterangan : Nilai rata-rata yang diikuti huruf kecil dan huruf kapital yang sama dalam baris yang sama tidak berbeda nyata pada BNT 5\%.

Rerata luas daun pada tabel 1 menunjukan bahwa perlakuan p1 (waktu pemangkasan $20 \mathrm{hst}$ ) memberikan hasil tertinggi dengan 0.60 , berbeda nyata terhadap perlakuan p2 (waktu pemangkasan 40 hst) 0.47 , namun tidak berbeda nyata dengan perlakuan p0 (tanpa pemangkasan) 0.33. hal ini menunjukan bahwa daun memiliki kondisi optimun dalam menerima cahaya pada saat proses fotosintesis.

P2 (pemangkasan $40 \mathrm{hst}$ ) menerima intensitas cahaya yang terlalu tinggi sehingga membuat daun menebal dan mengecil. Utami (2018) menyampaikan bahwa meningkatnya indeks luas daun berkorelasi dengan meningkatnya jumlah sel daun. Sedangkan meningkatnya ketebalan daun dipengaruhi oleh lapisan palisade yang membesar seiring dengan cahaya matahari yang diterima. Semakin meningkat cahaya matahari maka semakin tebal daun yang dihasilkan.
Sejalan dengan Buntoro, Regomulyo dan Trisnowati (2014) yang menyatakan bahwa tanaman yang terkena cahaya dengan intensitas tinggi biasanya memiliki jumlah daun lebih banyak dengan stomata yang relatif kecil dan bertekstur keras. Ukuran daun yang kecil dan tebal disebabkan oleh sel-sel daun mengecil, klorofil lebih sedikit dan tilakoid mengumpul.

\section{Jumlah Polong Segar Per Tanaman}

Hasil analisis menunjukan tidak adanya pengaruh yang nyata baik interaksi maupun sendiri. Pada perlakuan jenis varietas hasil tertinggi diperlihatkan oleh v1 (Varietas KP-1) dengan rerata jumlah polong 2.93 per tanaman tidak berbeda nyata dengan v2 (Varietas Katrina) yang menghasilkan rerata 2.61 buah per tanaman. Sejalan dengan Wijaya, Sumiya dan Setyabudi (2015) yang menyatakan bahwa perlakuan pemangkasan topping tidak 
memberikan pengaruh yang nyata terhadap jumlah buah tanaman mentimun.

Tabel 2. Rerata Jumlah Polong Segar Pertanaman (buah)

\begin{tabular}{ll}
\hline \multicolumn{1}{c}{ Perlakuan } & Jumlah Polong (buah) \\
\hline Varietas (V) & \\
v1 (KP-1) & $2.93 \mathrm{a}$ \\
v2 (Katrina) & $2.61 \mathrm{a}$ \\
\hline Waktu Pemangkasan (P) & \\
p0 (Tanpa Pemangkasan) & $2.87 \mathrm{a}$ \\
p1 (pemangkasan 20 hst) & $2.86 \mathrm{a}$ \\
p2 (Pemangkasan 40 hst) & $2.58 \mathrm{a}$ \\
\hline KK P \% & $16.42 \%$ \\
\hline
\end{tabular}

Keterangan : Nilai rata-rata yang diikuti huruf kecil dan huruf kapital yang sama dalam baris yang sama tidak berbeda nyata pada BNT 5\%.

Fotosintesis sangat sensitif terhadap variasi ketersediaan cahaya matahari dan CO2. Selain itu fotosintesis juga dipengaruhi oleh beberapa faktor seperti suhu dan nutrisi. Selain perlakuan pemangkasan diperlukan pula nutrisi yang cukup agar proses fotosintesis berjalan optimal. Menurut Utami (2018) faktorfaktor yang terlibat dalam proses fotosintesis mempunyai peran dalam skalanya masing-masing. Faktor yang berfluktuasi harian adalah suhu dan radiasi matahari yang diserap oleh daun. Sedangkan Faktor yang berfluktuasi dalam jangka yang lama adalah nutrisi dan kandungan air.

\section{Bobot 100 Biji}

Perlakuan jenis varietas dan waktu pemangkasan topping menunjukan adanya interaksi terhadap bobot 100 biji. Secara mandiri masing-masing faktor tidak menunjukan adanya perbedaan yang nyata.

Tabel 3. bobot 100 biji (g).

\begin{tabular}{cccc}
\hline & \multicolumn{3}{c}{ Bobot 100 Biji $(\mathrm{g})$} \\
\cline { 2 - 4 } Perlakuan & $\mathrm{p} 0$ & $\mathrm{p} 1$ & $\mathrm{p} 2$ \\
\hline $\mathrm{n} 1$ & $13.75 \mathrm{~b}$ & $16.25 \mathrm{a}$ & $15.00 \mathrm{a}$ \\
$\mathrm{v} 2$ & $\mathrm{~B}$ & $\mathrm{~A}$ & $\mathrm{AB}$ \\
& $16.25 \mathrm{a}$ & $15.50 \mathrm{~b}$ & $13.75 \mathrm{~b}$ \\
$\mathrm{KK}(\%)$ & $\mathrm{A}$ & $\mathrm{AB}$ & $\mathrm{B}$ \\
\hline
\end{tabular}

Keterangan : Nilai rata-rata yang diikuti huruf kecil dan huruf kapital yang sama dalam baris yang sama tidak berbeda nyata pada BNT 5\%.

Bobot 100 biji v1 (varietas KP-1) tertinggi diperlihatkan pada perlakuan $\mathrm{p} 1$ (pemangkasan $20 \mathrm{hst}$ ) 16.25 gram, nilai ini lebih tinggi dari deskripsi produk (13 - 15.5 gram). Hal ini menunjukan bahwa perlakuan pemangkasan topping $20 \mathrm{hst}$ dapat meningkatkan bobot biji tanaman kacang panjang varietas KP-1. Pada v2 
(Varietas Katrina) hasil tertinggi ditunjukan oleh p0 (tanpa pemangkasan) dengan 16.25 gram berbeda nyata dengan p2 (pemangkasan $40 \mathrm{hst}$ ) yang menghasilkan 13.75 gram namun tidak berbeda nyata dengan perlakuan p1 (pemangkasan $20 \mathrm{hst}$ ) yang memiliki bobot 15.50 gram.

Rahmadani, Mulyani dan Sunarlim (2012) menyatakan bahwa selain faktor gen Pembentukan polong juga dipengaruhi oleh suhu. Suhu optimal untuk pembentukan polong adalah $26,6-32{ }^{\circ} \mathrm{C}$, sedangkan di lahan percobaan suhu maksimal rata-rata pada saat penelitian adalah $37.31{ }^{\circ} \mathrm{C}$. Faktor lingkungan diduga menjadi penyebab rendahnya produksi kacang panjang pada saat percobaan.

\section{Bobot Polong Segar Per Tanaman}

Hasil pengamatan bobot polong segar per tanaman dan analisis ragam tertera pada tabel 4. Hasil uji lanjut BNT taraf 5\% menunjukan adanya pengaruh interaksi antara varietas dan waktu pemangkasan topping terhadap rerata bobot polong segar per tanaman pada panen.

Tabel 4. Rerata Bobot Polong Segar Per Tanaman (g)

\begin{tabular}{cccc}
\hline & \multicolumn{3}{c}{ Berat Polong Segar $(\mathrm{g})$} \\
\cline { 2 - 4 } Perlakuan & $\mathrm{p} 0$ & $\mathrm{p} 1$ & $\mathrm{p} 2$ \\
\hline $\mathrm{v} 1$ & $204.50 \mathrm{~b}$ & $348.20 \mathrm{a}$ & $187.20 \mathrm{a}$ \\
$(\mathrm{KP}-1)$ & $\mathrm{B}$ & $\mathrm{A}$ & $\mathrm{B}$ \\
v2 & $370.70 \mathrm{a}$ & $136.80 \mathrm{~b}$ & $165.00 \mathrm{a}$ \\
Katrina $)$ & $\mathrm{A}$ & $\mathrm{B}$ & $\mathrm{B}$ \\
\hline KK $(\%)$ & & $20.28 \%$ & \\
\hline
\end{tabular}

Keterangan : Nilai rata-rata yang diikuti huruf kecil dan huruf kapital yang sama dalam baris yang sama tidak berbeda nyata pada BNT 5\%.

Pada tabel 4 menunjukan bahwa taraf jenis varietas $\mathrm{v} 1(\mathrm{KP}-1)$ perlakuan $\mathrm{p} 1$ (pemangkasan 20 hst) memperlihatkan berat polong segar per tanaman tertinggi sebesar 348.20 gram berbeda nyata dengan perlakuan lainnya. Pada taraf jenis varietas v2 (Katrina) perlakuan p0 (tanpa pemangkasan) memperlihatkan berat polong segar per tanaman tertinggi sebesar 370.70 gram, berbeda nyata dengan perlakuan lainnya.

Menurut Simanjuntak et al, (2019) Tanaman yang dilakukan pemangkasan memiliki bobot yang lebih tinggi karena proses pembungaanya berjalan optimal sehingga polong yang dihasilkanpun memiliki bobot yang optimal pula. Dalam penelitiannya Pasaribu et al, (2015) menyatakan bahwa bobot perbuah tertinggi dihasilkan oleh tanaman dengan pemangkasan cabang utama sedangkan perlakuan tanpa pemangkasan menghasilkan polong yang lebih rendah. Hal ini terjadi karena fotosintat yang dihasilkan didistribusikan dengan sempurna untuk pembentukan buah.

\section{KESIMPULAN}

Hasil penelitian menunjukan bahwa varietas KP-1 menunjukan hasil tertinggi pada perlakuan pemangkasan 20 hst dengan bobot 100 biji sebesar 16.25 gram dan bobot polong segar 348.20 gram per tanaman. Sedangkan varietas Katrina menunjukan hasil tertinggi pada perlakuan tanpa pemangkasan topping dengan bobot 100 biji sebesar 16.25 gram dan bobot polong segar 370 gram per tanaman. 


\section{UCAPAN TERIMAKASIH}

Terima kasih kepada semua pihak yang terlibat dalam penelitian ini, terkhusus bagi Fakultas Pertanian Universitas Singaperbangsa Karawang dan Balai Penelitian Tanaman Sayuran (Balitsa) Lembang yang telah memberikan arahan dan masukan dalam proses penelitian hingga penulisan.

\section{DAFTAR PUSTAKA}

Badan Pusat Statistik, (2018). Produksi Tanaman Sayuran Kacang Panjang di Indonesia.

Badrudin, U., S. Jazilah dan A. Setiawan. 2011. Upaya peningkatan produksi mentimun (Cucumis sativus L.) melalui waktu pemangkasan pucuk dan pemberian pupuk fosfat. Jurnal Biofarm. 1(20): 18-28

Buntoro, B. H, R. Regomulyo, S. Trisnowati. 2014. Pengaruh takaran pupuk kandang dan intensitas cahaya terhadap pertumbuhan dan hasil temu putih (Curcuma zedoaria L.). Vegetika. 3(4):29-39.

Kurniawati, A., Guritno, B. 2016. Pengaruh Pemangkasan terhadap Pertumbuhan dan Hasil Tiga Varietas Mentimun (Cucumis sativus L) Hibrida. Jurnal Penelitian Tanaman. Vol. 6. No.6. 1164-1170.

Parawansa, Rante R. 2014. Plant response long bean (Vigna sinensis L.) shoons pruning of age increase production. Advances in Environmental Biology 8(12): 519-525.

Pasaribu, P. R., Yetti H, Nurbaiti. 2015. Pengaruh Pemangkasan Cabang Utama Dan Pemberian Pupuk Pelengkap Cair Organik Terhadap Pertumbuhan dan Produksi
Tanaman Tomat (Lycopersicum esculentum Mill.). Jurnl Online Mahasiswa Fakultas Pertanian Universitas Riau. Vol 2, No 2.

Rahmadani, E., Mulyani, A., Sunarlim N. 2012. Performan Sifat Vegetatif, Komponen Hasil, dan Hasil Berbagai Varietas Kacang Hijau (Vigna Radiata L.) di Media Gambut. Jurnal Agroteknologi, Vol. 2 No. 2: 7-14.

Rasyid P. 2012. Manfaat Kacang Panjang Bagi Tubuh.

Safitri A. I., Aini N. 2018. Pengaruh Waktu Pemangkasan Pucuk dan Konsentrasi Giberelin pada Pertumbuhan dan Hasil Baby Buncis (Phaseoulus vulgaris L.). Jurnal Prouksi Tanaman. Vol. 6 No. 4.

Simanjuntak, I.S., Astiningsih, A.A.M., Mayun, I.A. 2019. Pengaruh Pemangkasan Cabang Lateral Terhadap Hasil Polong Segar Tanaman Kacang Panjang (Vigna sinensis L.) E-Jurnal Agroekoteknologi Vol. 8, No. 1, Januari 2019.

Soedomo, R.P. 2012. Uji Keunggulan Calon Varietas Unggul Kacang Panjang (Vigna sesquipedalis (L) Fruhw) Di Daerah Blitar. Jurnal Agrotropika 18(2): 63-72.

Sutrisno dan A. Wijanarko. 2017. Respon Tanaman Kedelai terhadap Waktu Pemangkasan Pucuk. Balai Penelitian Tanaman Aneka Kacang dan Umbi. Malang.

Utami. 2018. Pengaruh Cahaya Terhadap Pertumbuhan Tanaman. Fakultas Pertanian Universitas Udayana. 
Wijaya. M. K, Sumiya D. Y dan Setyobudi.

L. (2015). Kajian Pemangkasan

Pucuk Terhadap Pertumbuhan dan

Produksi Baby Mentimun (Cucumis

sativus L). Jurnal Produksi

Tanaman, Volume 3, Nomor 4. 